\title{
A facile and sensitive peptide-modulating graphene oxide nanoribbon catalytic nanoplasmon analytical platform for human chorionic gonadotropin
}

This article was published in the following Dove Press journal: International Journal of Nanomedicine

\author{
Aihui Liang ${ }^{1,2, *}$ \\ Chongning $\mathrm{Li}^{1,2, *}$ \\ Dan $\mathrm{Li}^{1,2, *}$ \\ Yanghe Luo ${ }^{1-3}$ \\ Guiqing Wen ${ }^{1,2}$ \\ Zhiliang Jiang ${ }^{1,2}$
}

'Key Laboratory of Ecology of Rare and Endangered Species and Environmental Protection, Guangxi Normal University, Ministry of Education, ${ }^{2}$ Guangxi Key Laboratory of Environmental Pollution Control Theory and Technology, Guilin University of Technology, Guilin, ${ }^{3} \mathrm{School}$ of Food and Bioengineering, Hezhou University, Hezhou, China

*These authors contributed equally to this work
Correspondence: Guiqing Wen; Zhiliang Jiang

Guangxi Normal University, Number 15 Yucai Road, Guilin 541004, China Email gqwen@mailbox.gxnu.edu.cn; zljiang@mailbox.gxnu.edu.cn

\begin{abstract}
The nanogold reaction between $\mathrm{HAuCl}_{4}$ and citrate is very slow, and the catalyst graphene oxide nanoribbon (GONR) enhanced the nanoreaction greatly to produce gold nanoparticles (AuNPs) that exhibited strong surface plasmon resonance (SPR) absorption (Abs) at $550 \mathrm{~nm}$ and resonance Rayleigh scattering (RRS) at $550 \mathrm{~nm}$. Upon addition of the peptide of human chorionic gonadotropin (hCG), the peptide could adsorb on the GONR surface, which inhibited the catalysis. When hCG was added, peptides were separated from the GONR surface due to the formation of stable peptide-hCG complex, which led to the activation of GONR catalytic effect. With the increase in hCG concentration, the RRS and Abs signal enhanced linearly. The enhanced RRS value showed a good linear relationship with hCG concentration in the range of $0.2-20 \mathrm{ng} / \mathrm{mL}$, with a detection limit of $70 \mathrm{pg} / \mathrm{mL}$. Accordingly, two new GONR catalytic RRS/Abs methods were established for detecting hCG in serum samples.
\end{abstract}

Keywords: nanocatalysis, graphene oxide nanoribbon, peptide regulation, hCG, RRS

\section{Introduction}

Nanoenzyme is a kind of mimetic enzyme that has unique properties and catalytic function. It has the characteristics of high efficiency, stability, economy and largescale preparation and has been applied in different fields of materials science, physics, chemistry, biology, medicine, and environment. ${ }^{1-3}$ The nanomaterials with nano analog enzyme activity have important significance in analytical chemistry. At present, the analytical application is mainly involved in the detection of heavy metal ions and biological molecules. ${ }^{3-6}$ Seok and Jongsoo ${ }^{3}$ detected mercury ions using ssDNA magnetic nanoparticles to inhibit the oxidation of $\mathrm{H}_{2} \mathrm{O}_{2}$ o-phenylenediamine to make no color change; the detection range was $5-75 \mu \mathrm{moL} / \mathrm{L}$. Li et $\mathrm{al}^{4}$ used the principle that mercury ions inhibited the color reaction of oxidation of tetramethyl benzidine catalyzed by nano lead mimetic enzyme to analyze $\mathrm{Hg}^{2+}$ in water samples, with a detection limit (DL) of $7.2 \mathrm{nmoL} / \mathrm{L}$. Peng et $\mathrm{al}^{5}$ detected mercury and copper using the principle of fluorescence quenching based on the specific binding of the fluorescent silver nanoclusters and the heavy metal ions; the detection ranges were $6-160 \mathrm{nmoL} / \mathrm{L}$ and 6-240 $\mathrm{nmoL} / \mathrm{L}$, respectively. Lien et $\mathrm{al}^{6}$ used fluorescence enhancement to detect thrombin due to amplex reagent (AR) for hydrogen peroxide oxidation catalyzed by thrombin transforming protein-mediated Bi-gold nanoparticles (AuNPs). Wang et $\mathrm{al}^{7}$ reduced the $\mathrm{DL}$ of $\mathrm{H}_{2} \mathrm{O}_{2}$ to $30 \mathrm{nmoL} / \mathrm{L}$ successfully by resonance Raman scattering with the oxidation of tetramethyl benzidine catalyzed by $\mathrm{Au@Ag} \mathrm{nanoparticles.} \mathrm{Jiang} \mathrm{et} \mathrm{al}{ }^{8}$ achieved a low concentration using the glucose detection method, which was based 
on the catalytic effect of nanogold by spectrophotometry, with a detection range of $2-10 \mathrm{nmoL} / \mathrm{L}$. Wang et $\mathrm{al}^{9}$ used $\mathrm{Cu}^{2+}$-ion-modified graphene oxide (GO) nanoparticles as a heterogeneous catalyst mimicking functions of horseradish peroxidase (HRP), and a simple colorimetric method was proposed to detect $30-140 \mu \mathrm{M}$ ascorbic acid. ${ }^{10}$ Our research group has established some sensitive resonance Rayleigh scattering (RRS) and surface enhanced Raman scattering methods for rapid detection of melamine, ${ }^{11} \mathrm{PDGF}^{12}$ and $\mathrm{Cu},{ }^{13}$ based on the nanoparticle probe aggregation and catalysis. Graphene oxide nanoribbons (GONRs) were prepared by using the method of facile unzipping of nitrogen-doped multiwalled carbon nanotubes (N-MWCNTs) with the help of microwave energy, ${ }^{14,15}$ which exhibited good water solubility and has been used in nanoanalysis. Zhang et $\mathrm{al}^{16}$ reported a GONR-modified electrochemical biosensor for the detection of $0.25-1.25 \mathrm{mmol} / \mathrm{L}$ amino acid. Dong et $\mathrm{al}^{17}$ developed a GONR biosensor for determination of 5-100 $\mu \mathrm{mol} / \mathrm{L}$ ATP. Zhu et al ${ }^{18}$ fabricated an MWCNT@GONR electrochemical sensor for 8-500 nmol/L polycyclic aromatic amines. In recent years, nanoplasmonic sensors have become widely used in medical, biotechnology and environmental science. One of the most promising directions has been surface-based nanoplasmonic sensors, and the potential of such technologies is still emerging. ${ }^{19-21}$ To date, there have been no reports about GONR catalytic gold nanoplasmon RRS/absorption (Abs) analytical platform for human chorionic gonadotropin (hCG), based on peptide reaction-modulating nanoenzyme activity, without preparation of nanoprobes and nanoparticle aggregation.

hCG is a glycoprotein secreted by the placenta trophoblast cells, and it is an important medical diagnostic marker of pregnancy. hCG also is one of the important markers of clinical disease. Its content is closely related to some diseases, such as gestational trophoblastic disease, germ cell tumors and Down syndrome. ${ }^{22-24}$ In addition, the quantitative detection of hCG is of great significance to the analysis of clinical medicine and the abuse of stimulants. At present, the detection methods of hCG are mainly electrochemical immunoassay, radioimmunoassay, chemiluminescent immunoassay, fluorescence resonance energy transfer method and optical immunoassay. ${ }^{25-30}$ Among these methods, radioimmunoassay is widely used, but there are radiation hazards. The electrochemical immunoassay method has a high sensitivity, but the operation is complex. The cost of fluorescence immunoassay is low, but there is a fluorescence quenching effect. Immunogold method is the most mature and widely used method for rapid detection of $\mathrm{hCG}$, but nanogold aggregation caused unstability. Most of these hCG immune analysis methods are based on the antigen-antibody reaction; the biggest disadvantage is that the antibody biological protein is easily affected by the environment deterioration and then affects the detection effect. Recently, some new assays were developed for the detection of hCG. ${ }^{31-36}$ Zhao et $\mathrm{al}^{31}$ reported a microplate magnetic chemiluminescence enzyme immunoassay for the determination of hCG using the alkaline phosphatase (ALP) as a labeled reagent and 3-(2'-spiroadamantane)-4-methoxy-4-(3"-phosphoryloxy) phenyl-1,2-dioxetane (AMPPD) as a chemiluminescence reagent. Chang et $\mathrm{al}^{32}$ combined catalytic gold nanoparticles with an hCG-specific peptide aptamer to create a simple, sensitive, label-free colorimetric assay for hCG. Ding and Yang $^{33}$ reported an antibody-free and label-free mechanism for detecting hCG using a short oligopeptide as an $\mathrm{hCG}$ receptor to bind $\mathrm{hCG}$, with a $\mathrm{DL}$ of $2 \mathrm{nmol} / \mathrm{L} \mathrm{hCG}$. Lei et $\mathrm{al}^{34}$ reported a strategy of chemiluminescence resonance energy transfer for detection of $0.12 \mathrm{nmol} / \mathrm{mL}$ hCG using graphene as an efficient long-range energy acceptor and the magnetic nanoparticles for magnetic separation and immobilization of HRP-labeled anti-hCG antibody. Chen et $\mathrm{al}^{35}$ reported an immunomagnetic assay for quantitative analysis of total $\beta$-subunit of hCG concentration in urine. The peptide of hCG was more stable than hCG antibody. Thus, Xia et $\mathrm{al}^{36}$ found a new and stable method to detect hCG by using the polypeptide nano silver electrochemical sensor with voltammetry, with a DL of $0.4 \mathrm{mIU} / \mathrm{mL}$. In this article, a new, simple, sensitive and low-cost nanoplasmon RRS/Abs analytical platform was developed, which was based on the polypeptide-hCG reaction regulation of GONR catalytic nanogold particle reaction.

\section{Materials and methods Materials}

A DXR SmartRaman Spectrometer (Thermo Fisher Scientific, Waltham, MA, USA) with a laser wavelength of $633 \mathrm{~nm}$ and a power of $3.0 \mathrm{~mW}$, Cary Eclipse Fluorescence Spectrophotometer (Varian Company, Salt Lake City, UT, USA), TU-1901 double beam ultraviolet (UV)-visible spectrophotometer (Beijing Purkinje General Instrument Co., Ltd., Beijing, China) and a thermostatic bath were used.

\section{Reagents}

A $0.50 \mathrm{mg}$ hCG (Beijing Boosen Biotechnology Co., Ltd., Beijing, China) freeze-dried powder was mixed with $1.0 \mathrm{~mL}$ water and diluted to $10 \mathrm{~mL}$; hCG polypeptide (HP; Biological Engineering Shanghai Limited by Share Ltd., Shanghai, China) was prepared by using Pro-Pro-Leu-Arg-IleAsn-Arg-His-Ile-Leu-Thr-Arg (PPLRINRHILTR), 
$1.0 \% \mathrm{HAuCl}_{4} \cdot 4 \mathrm{H}_{2} \mathrm{O}$ (Sinopharm Chemical Reagent Co. Ltd., Shanghai, China), 1.0\% trisodium citrate (TCA; Guangdong Shantou Timong Chemical Factory, Guangzhou, China) and $0.1 \mathrm{~mol} / \mathrm{L} \mathrm{HCl}$. All reagents were analytically pure, and water was double distilled.

GONR was prepared by the modified $\mathrm{KMnO}_{4}$ procedure. Briefly, $50 \mathrm{mg}$ of MWCNT powder was added into a $50 \mathrm{~mL}$ flask containing $10 \mathrm{~mL}$ concentrated $\mathrm{H}_{2} \mathrm{SO}_{4}$ solution for 1 hour. Then, $500 \mathrm{mg}$ of $\mathrm{KMnO}_{4}$ was added and heated at $60^{\circ} \mathrm{C}$ for $2 \mathrm{~h}$. The product was poured into a $5 \mathrm{~mL} 30 \%$ $\mathrm{H}_{2} \mathrm{O}_{2}$ solution that was cooled by ice water. The mixture was dispersed by ultrasonic treatment for $10 \mathrm{~min}$ and centrifuged at 7,000 rpm for $10 \mathrm{~min}$ to obtain the supernatant containing $230 \mu \mathrm{g} / \mathrm{mL}$ GONR that was calculated by adding MWCNT. Before use, it was neutralized with $50 \mathrm{mmol} / \mathrm{L} \mathrm{NaOH}$ and then was diluted to the desired concentration.

\section{Methods}

A moderate amount of hCG and $100 \mu \mathrm{L}$ of $1.4 \mu \mathrm{mol} / \mathrm{L}$ HP were added to a $5 \mathrm{~mL}$ test tube for $\sim 15 \mathrm{~min}$ and then $480 \mu \mathrm{L}$ of $1 \mu \mathrm{g} / \mathrm{mL}$ GONR was added and mixed well. After $\sim 10 \mathrm{~min}$, $75 \mu \mathrm{L}$ of $3.4 \mathrm{mmol} / \mathrm{L} \mathrm{TCA}, 150 \mu \mathrm{L}$ of $0.01 \mathrm{~mol} / \mathrm{L} \mathrm{HCl}$ and $100 \mu \mathrm{L}$ of $0.1 \%(84 \mu \mathrm{mol} / \mathrm{L}) \mathrm{HAuCl}_{4}$ were put into the test tube, diluted to $1.5 \mathrm{~mL}$, mixed well, incubated at $60^{\circ} \mathrm{C}$ in a water bath for $\sim 12$ min and cooled with tap water. Finally, the mixture was diluted to $2 \mathrm{~mL}$ with water. The mixture was transferred into a quartz cell, and its RRS spectra were recorded. The RRS peak intensity at $550 \mathrm{~nm}(I)$ and the $I_{0}$ blank without hCG were recorded, and the value of $\Delta I=I-I_{0}$ was calculated.

\section{Results and discussion \\ Analysis principle}

Nanocatalytic reaction is an important way for signal amplification and enhancing sensitivity. The new nanocatalytic particle reaction of citrate- $\mathrm{HAuCl}_{4}$ nanoparticles was investigated and used in nanoplasmon molecular spectral analysis. The AuNP reaction was very slow in the absence of nanocatalyst. Hence, in the non-catalytic reaction system, there was a low concentration of the produced AuNPs with weak surface enhanced Raman scattering signal due to small amount of VB4r molecular probes being adsorbed on the AuNPs. The GONRs with abundant surface hydroxyl groups had a strong catalytic effect on the AuNP reaction between citrate and $\mathrm{HAuCl}_{4}$. The $\mathrm{AuCl}_{4}^{-}$and citrate could adsorb on the GONR catalyst surface, and redox reaction took place to form $\mathrm{Au}$. The surface electrons of GONR enhanced the electron transfer in the redox reaction and speeded up the redox reaction. The produced AuNPs exhibited surface plasmon resonance (SPR)RRS and Abs, and both increased with GONR concentration. HP had a high affinity with GONR and a high specificity for targeting hCG. It could easily adsorb to the GONR surface through electrostatic attraction that weakened GONR catalysis. When the hCG was present in the solution, the HP selectively recognized and tightly bound to hCG to form a stable $\mathrm{HP}-\mathrm{hCG}$ complex that escaped the nanosurface to recover the nanocatalysis. With the increase in hCG concentration, the catalysis enhanced due to the increase in the free GONR concentration. Thus, we could establish a new nanogold plasmon $\mathrm{RRS} / \mathrm{Abs}$ platform for the determination of hCG (Figure 1) with high sensitivity, high selectivity and simplicity.

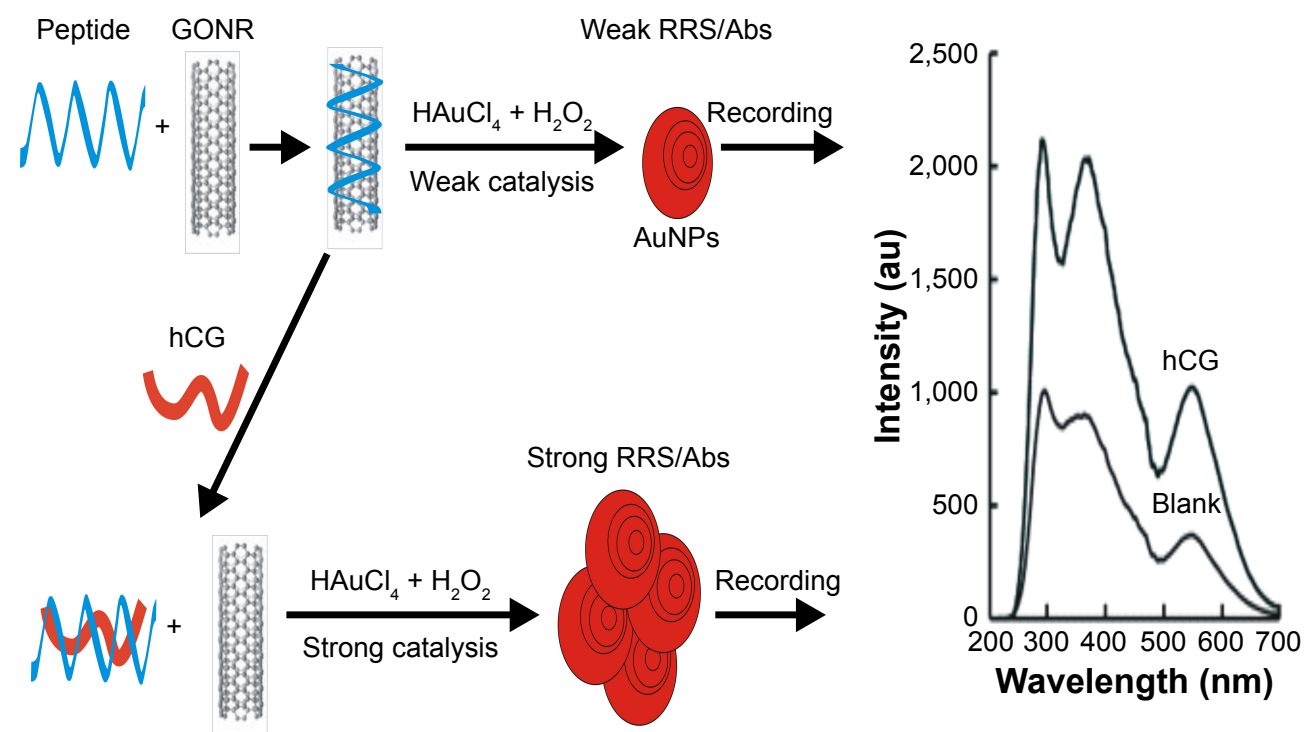

Figure I Scheme of peptide-controlling GONR catalytic reaction-RRS detection of hCG.

Abbreviations: Abs, absorption; AuNP, gold nanoparticle; au, atomic unit; GONR, graphene oxide nanoribbon; hCG, human chorionic gonadotropin; RRS, resonance Rayleigh scattering. 


\section{RRS spectra}

RRS is a simple and sensitive molecular spectral technique. It is suitable for nanoparticle reaction and is selected for the study of the nanocatalytic system. To date, there have been no reports about RRS study of the GONR catalytic nanogold reaction and its coupling with immunoreactions without nanoparticle aggregation that could cause instability of the analytical system. Thus, RRS was selected for the study of the analytical system. The catalysis of GONR and GO in the redox reaction was considered; as the GONR is stronger than the GO, GONR was selected as the nanoenzyme. For the $\mathrm{HP}-\mathrm{hCG}-\mathrm{GONR}-\mathrm{HAuCl}$-TCA analytical system, the generated AuNPs exhibited three RRS peaks at 290, 370 and 550. The RRS peak at $550 \mathrm{~nm}$ had a good linear relationship between the signal and hCG concentration and was selected for assay of hCG (Figure 2A). The nanocatalytic system of GONR-HAuCl-TCA exhibited three RRS peaks at 290 and $545 \mathrm{~nm}$ (Figure 2B), and the RRS peak intensity increased with GONR concentration. Upon addition of HP, HP could inhibit the catalytic activity of GONR nanoenzyme; the
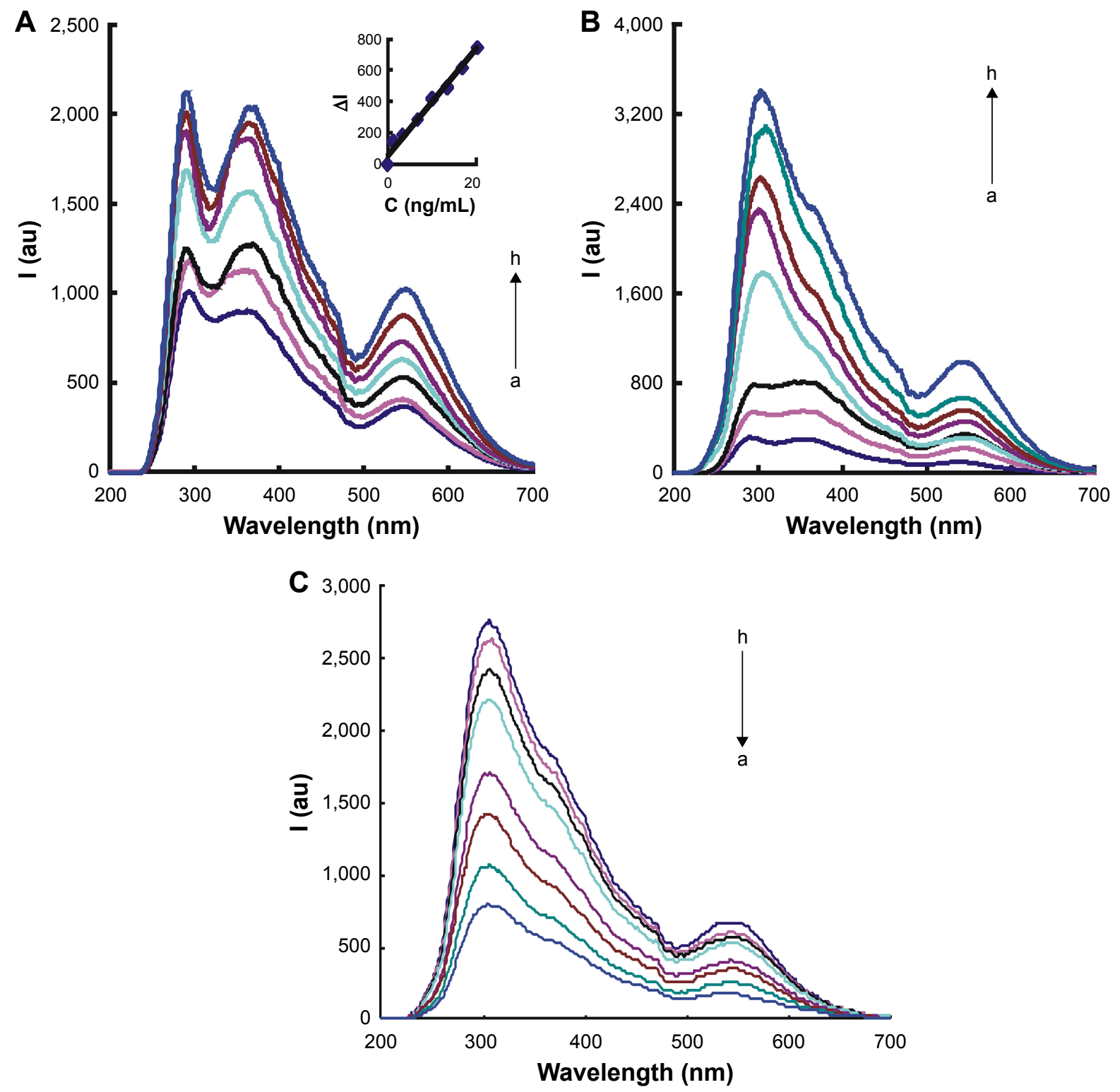

Figure 2 RRS spectra of the GONR systems.

Notes: (A) HP-hCG-GONR-HAuCl - TCA system - a: 35 nmoL/L HP +240 ng/mL GONR +0.167 mmoL/L HCl +0.34 mmoL/L TCA +5.6 $\mu \mathrm{moL} / \mathrm{L} \mathrm{HAuCl}$; b: a+0.33 ng/mL hCG; c: a+l ng/mL hCG; d: a+2 ng/mL hCG; e: a+4 ng/mL hCG; f: a+6 ng/mL hCG; g: a+l0 ng/mL hCG; and h: a+l3.33 ng/mL hCG. The inset graph was the working curve. (B) GONR-HAuCl$-\mathrm{TCA}$ system - a: $0.167 \mathrm{mmoL} / \mathrm{L} \mathrm{HCl}+0.34 \mathrm{mmoL} / \mathrm{L} \mathrm{TCA}+5.6 \mu \mathrm{moL} / \mathrm{L} \mathrm{HAuCl}$; b: a+l6 ng/mL GONR; c: a+40 ng/mL GONR; d: a+80 ng/mL GONR; e: a+1 20 ng/mL GONR; f: a+160 ng/mL GONR; g: a+240 ng/mL GONR; and h: a+320 ng/mL GONR. (C) HP-GONR-HAuCl -TCA system - a: 240 ng/mL GONR $+0.167 \mathrm{mmoL} / \mathrm{L} \mathrm{HCl}+0.34 \mathrm{mmoL} / \mathrm{L} \mathrm{TCA}+5.6 \mu \mathrm{moL} / \mathrm{L} \mathrm{HAuCl}$; b: a+I.4 nmoL/L HP; c: a+3.5 nmoL/L HP; d: a+7 nmoL/L HP; e: a+I0.5 nmoL/L HP; f: a+I4 nmoL/L HP; g: $\mathrm{a}+2 \mathrm{I} \mathrm{nmoL} / \mathrm{L} \mathrm{HP}$; and $\mathrm{h}: \mathrm{a}+28 \mathrm{nmoL} / \mathrm{L} \mathrm{HP}$.

Abbreviations: C, concentration; I, intensity; RRS, resonance Rayleigh scattering; GONR, graphene oxide nanoribbon; HP, hCG polypeptide; hCG, human chorionic gonadotropin; TCA, trisodium citrate. 
catalytic activity decreased and the two RRS peaks at 300 and $550 \mathrm{~nm}$ decreased with the increasing HP concentration (Figure 2C).

\section{Ultraviolet Abs spectra}

A spectrophotometer is a very simple and low-cost spectral instrument that was selected for studying the SPR Abs of nanogold nanoparticles. For the HP-hCG-GONR-HAuCl ${ }_{4}$ TCA system, the SPR Abs peak at $540 \mathrm{~nm}$ increased with hCG concentration and was selected for assay of hCG (Figure 3A). The GONR catalyzed the TCA reduced $\mathrm{HAuCl}_{4}$ to form AuNPs with a SPR Abs peak at $550 \mathrm{~nm}$ (Figure 3B) that corresponds to the RRS peak at $545 \mathrm{~nm}$, in which the peak increased with the GONR increasing. HP can adsorb on the GONR surface and inhibit the catalysis; the SPR Abs peak decreased with the increasing HP concentration (Figure 3C).

\section{Catalysis and inhibition}

In the experimental conditions, the reduction of $\mathrm{HAuCl}_{4}-$ TCA could be catalyzed by GONR or GO to form AuNPs. The RRS and Abs values increased with the increasing catalyst concentration. The catalytic action of GONR was stronger than that of the GO, because the slope of GONR is
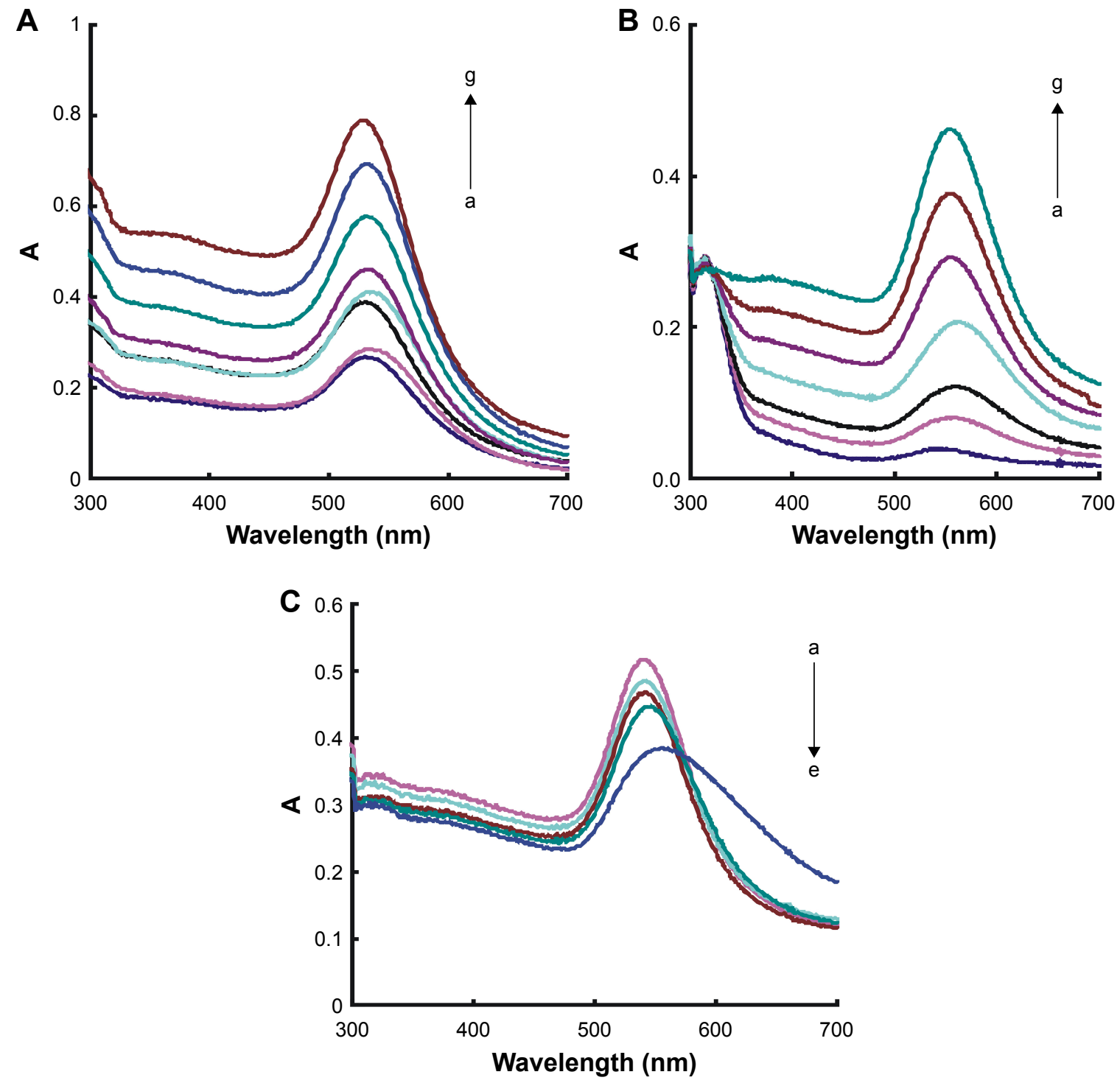

Figure 3 UV spectra of the GONR systems.

Notes: (A) HP-hCG-GONR-HAuCl - TCA system - a: $35 \mathrm{nmol} / \mathrm{L} \mathrm{HP}+240 \mathrm{ng} / \mathrm{mL} \mathrm{GONR}+0.167 \mathrm{mmol} / \mathrm{L} \mathrm{HCl}+0.34 \mathrm{mmoL} / \mathrm{L} \mathrm{TCA}+5.6 \mu \mathrm{moL} / \mathrm{L} \mathrm{HAuCl}$; b: a+0.67 ng/mL hCG; c: a+l.67 ng/mL hCG; d: a+3.33 ng/mL hCG; e: a+6.67 ng/mL hCG; f: a+10 ng/mL hCG; and g: a+13.33 ng/mL hCG. (B) GONR-HAuCl-TCA system - a: 0.167 mmoL/L $\mathrm{HCl}+0.34 \mathrm{mmoL} / \mathrm{L} \mathrm{TCA}+5.6 \mu \mathrm{mol} / \mathrm{L} \mathrm{HAuCl}$; b: a+l6 ng/mL GONR; c: a+40 ng/mL GONR; d: a+80 ng/mL GONR; e: a+I20 ng/mL GONR; f: a+l60 ng/mL GONR; and g: a+240 ng/mL GONR. (C) HP-GONR-HAuCl - TCA system - a: 240 ng/mL GONR +0.167 mmoL/L HCl +0.34 mmoL/L TCA +5.6 $\mu \mathrm{moL} / \mathrm{L} \mathrm{HAuCl}$; b: a+5 nmoL/L HP; c: $a+10$ nmoL/L HP; d: a+20 nmoL/L HP; and e: a+30 nmoL/L HP.

Abbreviations: A, absorbance; UV, ultraviolet; GONR, graphene oxide nanoribbon; HP, hCG polypeptide; hCG, human chorionic gonadotropin; TCA, trisodium citrate. 
Table I Comparison of the nanocatalysis and the inhibition of $\mathrm{HP}$ on the reaction of TCA- $-\mathrm{HAuCl}_{4}$

\begin{tabular}{llll}
\hline System & Linear range & Linear equation & $\begin{array}{l}\text { Correlation } \\
\text { coefficient }\end{array}$ \\
\hline GONR & $1.0-30 \mathrm{ng} / \mathrm{mL}$ GONR & $\Delta \mathrm{I}_{545 \mathrm{~nm}}=61.5 \mathrm{C}+203$ & 0.9918 \\
AuNP & $1.0-25 \mathrm{ng} / \mathrm{mL}$ AuNP & $\Delta \mathrm{I}_{545 \mathrm{~nm}}=58.3 \mathrm{C}+150$ & 0.9834 \\
$(\mathrm{~d}=10 \mathrm{~nm})$ & & & \\
HP-GONR & $2.0-30 \mathrm{nmoL} / \mathrm{L} \mathrm{HP}$ & $\Delta \mathrm{I}_{545 \mathrm{~nm}}=47.8 \mathrm{C}+69.5$ & 0.9804 \\
GO & $2.0-30 \mathrm{ng} / \mathrm{mL} \mathrm{GO}$ & $\Delta \mathrm{I}_{545 \mathrm{~nm}}=36.9 \mathrm{C}-89.8$ & 0.9621 \\
\hline
\end{tabular}

Note: I is measured in au.

Abbreviations: HP, hCG polypeptide; TCA, trisodium citrate; GONR, graphene oxide nanoribbon; AuNP, gold nanoparticle; GO, graphene oxide; hCG, human chorionic gonadotropin; I, intensity; C, concentration; d, diameter.

larger than the GO due to the size of GONR being smaller than the GO. When HP was added into the system, the RRS peak and Abs values decreased with increasing HP concentration (Table 1). The reason was that HP could be attached to the surface of the nanocatalyst by physical electrostatic adsorption, so as to block the exchange between the redox electrons and catalyst surface electrons.

\section{Transmission electron microscopy}

Transmission electron microscopy (TEM) is used to observe the particulate particle size and surface morphology. The blank reaction solution of $\mathrm{HP}-\mathrm{hCG}-\mathrm{GONR}-\mathrm{HAuCl}{ }_{4}$ system was obtained by the procedure, and the TEM (Figure 4A) was recorded with particle average size of $80 \mathrm{~nm}$. When hCG was added into the solution, more AuNPs formed (Figure 4B and C); the particle size was 60 and $50 \mathrm{~nm}$.

\section{Optimization of analysis conditions}

The reaction conditions of $\mathrm{HP}-\mathrm{hCG}-\mathrm{GONR}-\mathrm{TCA}-\mathrm{HAuCl}_{4}$ were optimized according to the experimental method. The effect of HP concentration on $\Delta I$ was investigated when it reached $35 \mathrm{nmoL} / \mathrm{L}$. The value of $\Delta I$ was the largest (Figure 5A), so the selection of the concentration of HP was $35 \mathrm{nmoL} / \mathrm{L}$. The effects of GONR concentration on the catalytic system at $\Delta I$ were investigated; according to the result, $240 \mathrm{ng} / \mathrm{mL}$ GONR was selected for use (Figure 5B). The concentration of TCA was researched; when the TCA
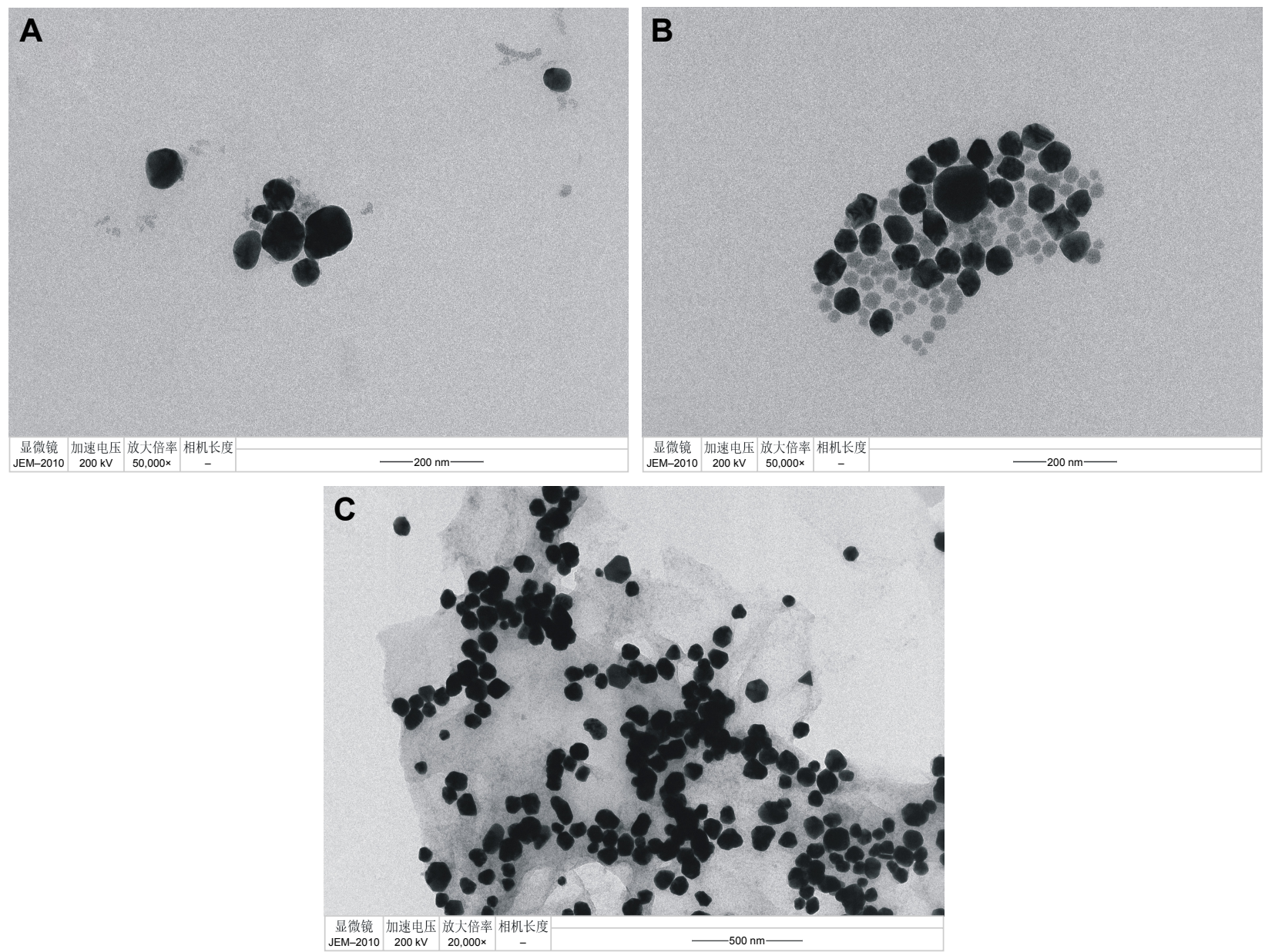

Figure 4 TEMs of analysis system.

Notes: (A) $35 \mathrm{nmoL} / \mathrm{L} \mathrm{HP}+240 \mathrm{ng} / \mathrm{mL}$ GONR $+0.167 \mathrm{mmoL} / \mathrm{L} \mathrm{HCl}+0.34 \mathrm{mmoL} / \mathrm{L} \mathrm{TCA}+5.6 \mu \mathrm{moL} / \mathrm{L} \mathrm{HAuCl}$. (B) A+4 ng/mL hCG. (C) A+I0 ng/mL hCG.

Abbreviations: TEM, transmission electron microscopy; HP, hCG polypeptide; GONR, graphene oxide nanoribbon; TCA, trisodium citrate; hCG, human chorionic gonadotropin. 

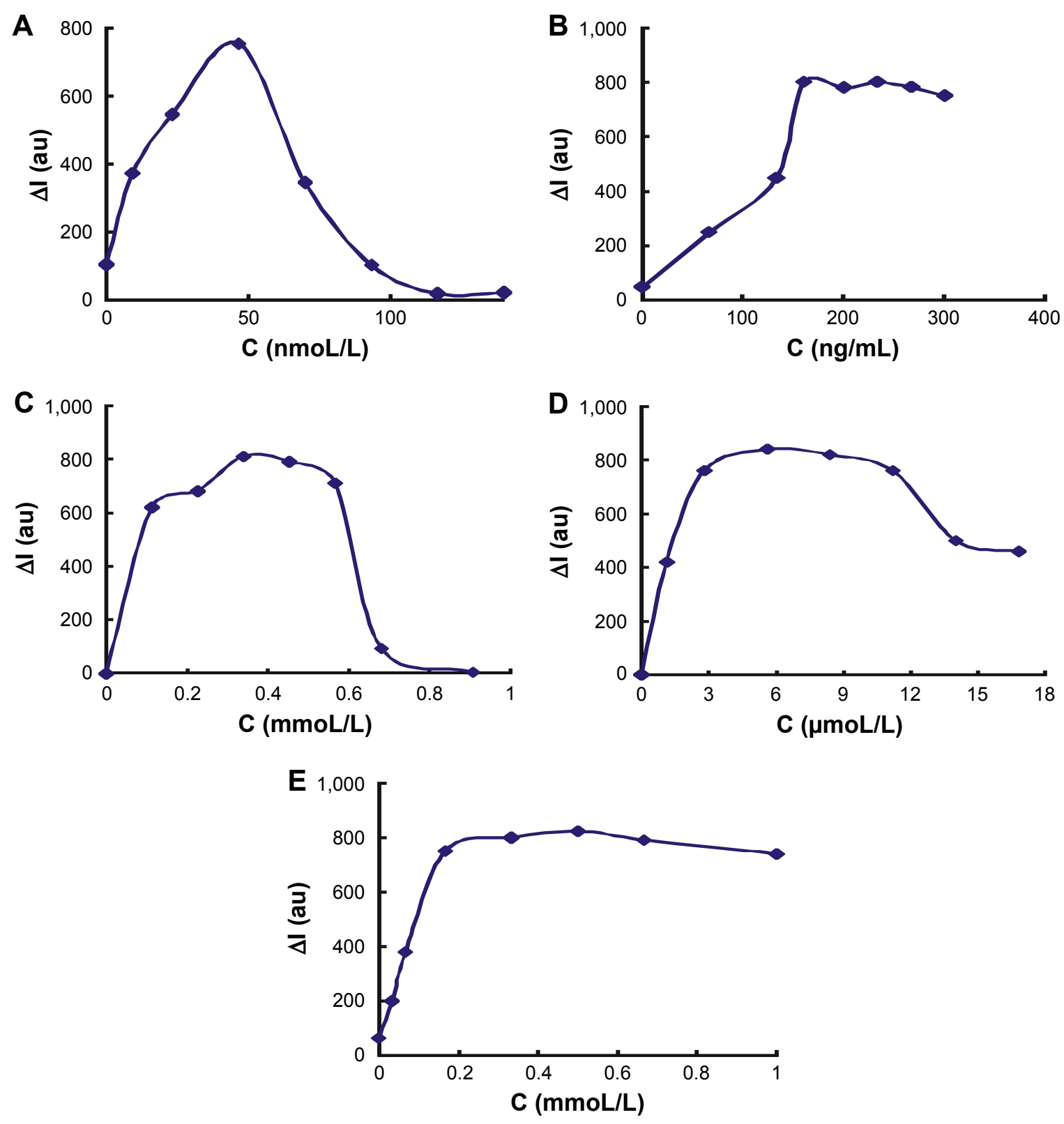

Figure 5 Effect of reagent concentration.

Notes: (A) HP $-10 \mathrm{ng} / \mathrm{mL} \mathrm{hCG}+240 \mathrm{ng} / \mathrm{mL}$ GONR $+0.167 \mathrm{mmoL} / \mathrm{L} \mathrm{HCl}+0.34 \mathrm{mmo} / \mathrm{L} \mathrm{TCA}+5.6 \mu \mathrm{moL} / \mathrm{L} \mathrm{HAuCl}$. (B) $\mathrm{GONR}-35 \mathrm{nmoL} / \mathrm{L} \mathrm{HP}+10 \mathrm{ng} / \mathrm{mL}$ $\mathrm{hCG}+\mathrm{GO}+0.167 \mathrm{mmoL} / \mathrm{L} \mathrm{HCl}+0.34 \mathrm{mmoL} / \mathrm{L} \mathrm{TCA}+5.6 \mu \mathrm{moL} / \mathrm{L} \mathrm{HAuCl}$. (C) TCA $-35 \mathrm{nmoL} / \mathrm{L} \mathrm{HP}+10 \mathrm{ng} / \mathrm{mL} \mathrm{hCG}+240 \mathrm{ng} / \mathrm{mL} \mathrm{GONR}+0.167 \mathrm{mmoL} / \mathrm{L} \mathrm{HCl}+5.6 \mu \mathrm{moL} / \mathrm{L}$ $\mathrm{HAuCl}_{4}$. (D) $\mathrm{HAuCl}_{4}-35 \mathrm{nmoL} / \mathrm{L} \mathrm{HP}+10 \mathrm{ng} / \mathrm{mL} \mathrm{hCG}+240 \mathrm{ng} / \mathrm{mL}$ GONR $+0.167 \mathrm{mmoL} / \mathrm{L} \mathrm{HCl}+0.34 \mathrm{mmoL} / \mathrm{L} \mathrm{TCA}+\mathrm{HAuCl}{ }_{4}$. (E) $\mathrm{HCl}-35 \mathrm{nmoL} / \mathrm{L} \mathrm{HP}+10 \mathrm{ng} / \mathrm{mL}$ $\mathrm{hCG}+240 \mathrm{ng} / \mathrm{mL} \mathrm{GONR}+\mathrm{HCl}+0.34 \mathrm{mmoL} / \mathrm{L} \mathrm{TCA}+5.6 \mu \mathrm{moL} / \mathrm{L} \mathrm{HAuCl}$.

Abbreviations: HP, hCG polypeptide; hCG, human chorionic gonadotropin; GONR, graphene oxide nanoribbon; TCA, trisodium citrate; GO, graphene oxide; I, intensity; C, concentration

concentration was $0.34 \mathrm{mmoL} / \mathrm{L}$, the value of $\Delta I$ was the largest (Figure 5C); the selection of the concentration of TCA was $0.34 \mathrm{mmoL} / \mathrm{L}$; when the $\mathrm{HAuCl}_{4}$ concentration was $5.6 \mu \mathrm{moL} / \mathrm{L}$, the $\Delta I$ value was the largest (Figure $5 \mathrm{D}$ ); $5.6 \mu \mathrm{moL} / \mathrm{L} \mathrm{HAuCl}_{4}$ was selected. The dosage of $\mathrm{HCl}$ was optimized, and when the concentration of $\mathrm{HCl}$ was $0.167 \mathrm{mmoL} / \mathrm{L}, \Delta I$ reached the maximum value (Figure $5 \mathrm{E}$ ); $0.167 \mathrm{mmoL} / \mathrm{L} \mathrm{HCl}$ was chosen; The optimization of the aforementioned reaction was carried out at $60^{\circ} \mathrm{C}$ water bath condition; the reaction time was $10 \mathrm{~min}$. The reaction temperature and time were examined. A temperature of $60^{\circ} \mathrm{C}$ for 12 min was chosen for use (Figure 6).

\section{Working curve}

The working curves for hCG were obtained according to the experimental method. For the GONR analytical system, the enhanced values of the RRS peak at $550 \mathrm{~nm}$ and the Abs peak at $550 \mathrm{~nm}$ were linear with hCG concentration in the range of $0.2-20 \mathrm{ng} / \mathrm{mL}$ and $10-15 \mathrm{ng} / \mathrm{mL}$, respectively, with a linear equation of $\Delta I=91.5 C+34.0$ 

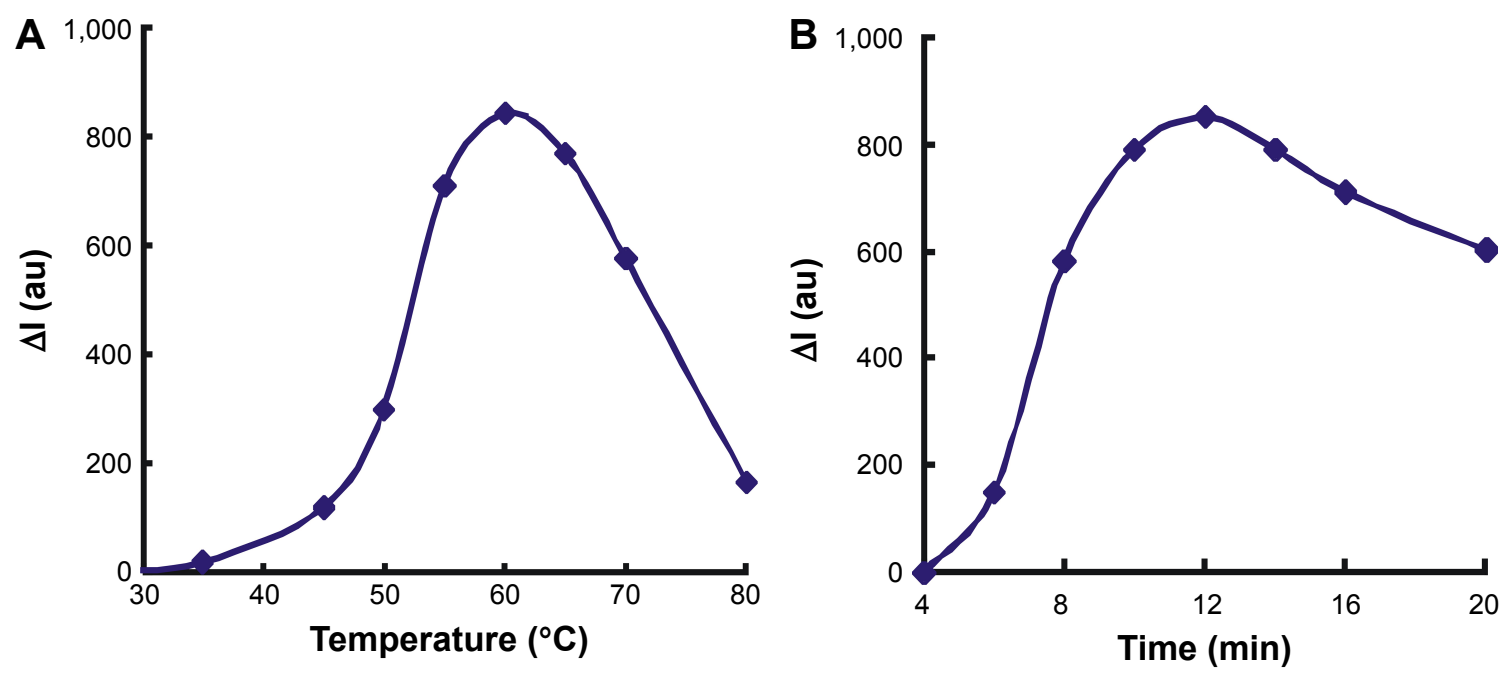

Figure $\mathbf{6}$ The effect of reaction temperature and time.

Notes: (A) Reaction temperature: $35 \mathrm{nmoL} / \mathrm{L} \mathrm{HP}+10 \mathrm{ng} / \mathrm{mL}$ hCG $+240 \mathrm{ng} / \mathrm{mL} \mathrm{GONR}+0.167 \mathrm{mmoL} / \mathrm{L} \mathrm{HCl}+0.34 \mathrm{mmoL} / \mathrm{L} \mathrm{TCA}+5.6 \mu \mathrm{moL} / \mathrm{L} \mathrm{HAuCl}{ }_{4}$. (B) time: $35 \mathrm{nmoL} / \mathrm{L}$ $\mathrm{HP}+10 \mathrm{ng} / \mathrm{mL}$ hCG $+240 \mathrm{ng} / \mathrm{mL}$ GONR $+0.167 \mathrm{mmoL} / \mathrm{L} \mathrm{HCl}+0.34 \mathrm{mmoL} / \mathrm{L} \mathrm{TCA}+5.6 \mu \mathrm{moL} / \mathrm{L} \mathrm{HAuCl}$.

Abbreviations: HP, hCG polypeptide; hCG, human chorionic gonadotropin; GONR, graphene oxide nanoribbon; TCA, trisodium citrate; I, intensity.

and $\Delta A_{550 \mathrm{~nm}}=0.0334 C+0.0223$, correlation coefficient of 0.9863 and 0.9661 , and DL of 0.07 and $3 \mathrm{ng} / \mathrm{mL}$, respectively.

We can see that the RRS analytical system is more sensitive than the Abs and was thus chosen for sample detection. Compared to the reported hCG methods, ${ }^{25-36}$ this RRS method is not only sensitive and selective but also facile, of low-cost and without nanoparticle aggregation. The clinical method of chemiluminescent immunoassay had a DL of $0.143 \mathrm{ng} / \mathrm{mL}$, limit of quantitation (LQ) of $5 \mathrm{ng} / \mathrm{mL}$ and linear range of $5-540 \mathrm{ng} / \mathrm{mL} \mathrm{hCG} ;{ }^{37}$ the DL and LQ of this RRS method are better than the clinical method, and the linear range of the two methods are close to each other, as the upper LQ divided by the lower LQ is 108 and 100 , respectively.

\section{Interference}

The effect of the coexisting substances on the determination of $10 \mathrm{ng} / \mathrm{mL}$ hCG was investigated. The tested common interfering ions and amino acids, IgG and IgM, did not interfere with the determination when the relative error was within $10 \%$ (Table 2). This indicated that this method had a good selectivity.

\section{Analysis of samples}

Seven serum samples of women were provided by the No 5 People's Hospital of Guilin, Guangxi, China. A $100 \mu \mathrm{L}$ sample was diluted to $10 \mathrm{~mL}$ with water before determination, the next detections were according to the procedure, and the content was equal to detection value multiplying dilution times of 100. In addition, recovery tests were performed, and the recovery was equal to ([Found value-Detection
value]/Added value) multiplied by $100 \%$. The results are listed in Table 3, and the recoveries were in the range of 90.1\%-106\%; the relative standard deviation (RSD) was in the range of $0.90 \%-3.97 \%$ according to five detection values. The obtained results were not obviously different from clinical diagnosis values from the No 5 People's Hospital of Guilin, ${ }^{37}$ so the results demonstrate that the method was reliable and practical in clinical detection.

\section{Conclusion}

In this work, GONR exhibited strong catalysis of the AuNP nanoreaction between $\mathrm{HAuCl}_{4}$ and citrate that produced an SPR Abs peak at $550 \mathrm{~nm}$ and an RRS peak at $550 \mathrm{~nm}$. Upon addition of HP, HP adsorbed on the surface of GONR nanoparticles, which blocked the electron transfer in the redox reaction and inhibited GONR catalytic action. When the target hCG was added, it reacted with HP to form stable

Table 2 Effect of coexisting substances

\begin{tabular}{llllll}
\hline $\begin{array}{l}\text { Coexisting } \\
\text { substance }\end{array}$ & $\begin{array}{l}\text { Relative } \\
\text { multiple }\end{array}$ & $\begin{array}{l}\text { Relative } \\
\text { error }(\%)\end{array}$ & $\begin{array}{l}\text { Coexisting } \\
\text { substance }\end{array}$ & $\begin{array}{l}\text { Relative } \\
\text { multiple }\end{array}$ & $\begin{array}{l}\text { Relative } \\
\text { error (\%) }\end{array}$ \\
\hline $\mathrm{K}^{+}$ & 100 & -1.0 & $\mathrm{SO}_{3}{ }^{2-}$ & 100 & -5.7 \\
$\mathrm{Ca}^{2+}$ & 100 & -7.4 & $\mathrm{NO}_{2}{ }^{-}$ & 100 & 8.0 \\
$\mathrm{Mg}^{2+}$ & 100 & -6.3 & $\mathrm{~S}_{2}{ }_{3}^{2-}$ & 100 & -6.0 \\
$\mathrm{Fe}^{3+}$ & 100 & -5.3 & $\mathrm{CO}_{3}^{2-}$ & 100 & -6 \\
$\mathrm{IgM}$ & 10 & -0.8 & $\mathrm{Glycine}^{2-}$ & 100 & -4 \\
$\mathrm{IgG}$ & 10 & -3.5 & Lysine & 100 & -7 \\
Tryptophan & 10 & 5.0 & Aspartic & 100 & 8.0 \\
& & & acid & & \\
Glutamate & 50 & 1.2 & Valine & 100 & -4.0 \\
Phenylalanine & 50 & -1.0 & Tyrosine & 100 & -6.0 \\
\hline
\end{tabular}


Table 3 Analysis of hCG samples

\begin{tabular}{llllllll}
\hline Sample & $\begin{array}{l}\text { Detection } \\
\text { value }(\mathbf{n g} / \mathbf{m L})\end{array}$ & $\begin{array}{l}\text { Content } \\
(\mathbf{n g} / \mathbf{m L})\end{array}$ & $\begin{array}{l}\text { Added value } \\
(\mathbf{n g} / \mathbf{m L})\end{array}$ & $\begin{array}{l}\text { Found value } \\
(\mathbf{n g} / \mathbf{m L})\end{array}$ & $\begin{array}{l}\text { Recovery } \\
(\%)\end{array}$ & $\begin{array}{l}\text { RSD } \\
(\%)\end{array}$ & $\begin{array}{l}\text { Ref value } \\
(\mathbf{n g} / \mathbf{m L})\end{array}$ \\
\hline 1 & 0.548 & 55.6 & 0.25 & 0.7842 & 94.5 & 1.05 & 56.6 \\
2 & 0.432 & 43.7 & 0.5 & 0.9258 & 98.8 & 3.97 & 45.7 \\
3 & 0.404 & 40.9 & 1.0 & 1.364 & 90.1 & 1.43 & 39.6 \\
4 & 0.480 & 48.6 & 0.5 & 1.010 & 106 & 0.90 & 46.9 \\
$5^{a}$ & 0.310 & 3.10 & 0.25 & 0.550 & 96.0 & 3.76 \\
6 & 5.24 & 524 & 5.0 & 10.52 & 105.6 & 2.85 & 518 \\
7 & 16.7 & 1,670 & 1.0 & 17.63 & 93.0 & 2.45 & 1,692 \\
\hline
\end{tabular}

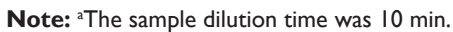

Abbreviations: hCG, human chorionic gonadotropin; Ref, reference; RSD, relative standard deviation.

HP-hCG complex and free GONR nanocatalyst that caused the SPR Abs value and the RRS intensity to increase due to the recovery of nanocatalysis. According to this principle, RRS and SPR Abs methods for detection of hCG were established based on the control of the catalytic reaction of GONR nano enzyme by the peptide reaction. With the increase in the amount of the analyte hCG, the RRS signal of the system increased gradually. The increased RRS intensity, $\Delta I$, at $550 \mathrm{~nm}$ showed a good linear relationship with the concentration of hCG in the range of $0.2-20 \mathrm{ng} / \mathrm{mL}$, with a DL of $70 \mathrm{pg} / \mathrm{mL}$. The RRS method was used in analyzing serum samples, with a recovery of $90.1 \%-106 \%$ and RSD of $0.90 \%-3.97 \%$.

\section{Acknowledgments}

This work is supported by the National Natural Science Foundation of China (numbers 21667006, 21767004, 21465006, and 21477025), the Doctor Scientific Research Foundation of Hezhou University (number HZUBS201608) and the Professor Scientific Research Foundation of Hezhou University (number HZUJS201613).

\section{Disclosure}

The authors report no conflicts of interest in this work.

\section{References}

1. Gao L-Z, Zhuang J, Nie L, et al. Intrinsic peroxidase-like activity of ferromagnetic nanoparticles. Nat Nanotechnol. 2007;2:577-583.

2. Li J-L, Sheng A-G, Hu J-M. Research progress of nanozymes and its application analysis. Chin J Appl Chem. 2016;33(11):1245-1252.

3. Seok KY, Jongsoo J. A simple colorimetric assay for the detection of metal ions based on the peroxidase-like activity of magnetic nanoparticles. Sens Actuators B. 2013;176:253-257.

4. Li W, Chen B, Zhang H-X, et al. BSA-stabilized Pt nanozyme for peroxidase mimetics and its application on colorimetric detection of mercury(II) ions. Biosens Bioelectron. 2015;66:251-258.

5. Peng J, Ling J, Zhang X-Q, et al. Sensitive detection of mercury and copper ions by fluorescent DNA/Ag nanoclusters in guanine-rich DNA hybridization. Spectrochim Acta A. 2015;137:1250-1257.

6. Lien C-W, Huang C-C, Chang H-T. Peroxidase-mimic bismuth-gold nanoparticles for determining the activity of thrombin and drug screening. Chem Commun. 2012;48(64):7952-7954.
7. Wang L-H, Shen A-G, Li X-C, et al. Inclusion of guest materials in aqueous coordination network shells spontaneously generated by reacting 2,5-dimercapto-1,3,4-thiadiazole with nanoscale metallic silver. RSC Adv. 2014;4:34294-34302.

8. Jiang X, Sun C-J, Guo Y, Nie G-J, Xu L. Peroxidase-like activity of apoferritin paired gold clusters for glucose detection. Biosens Bioelectron. 2015;64:165-170.

9. Wang S, Cazelles R, Liao WC, et al. Mimicking horseradish peroxidase and NADH peroxidase by heterogeneous $\mathrm{Cu}^{2+}$-modified graphene oxide nanoparticles. Nano Lett. 2017;17(3):2043-2048.

10. Fan S, Zhao M, Ding L, Li H, Chen S. Preparation of $\mathrm{Co}_{3} \mathrm{O}_{4} /$ crumpled graphene microsphere as peroxidase mimetic for colorimetric assay of ascorbic acid. Biosens Bioelectron. 2017;89:846-852.

11. Liang A-H, Zhou L-P, Qin H-M, Zhang Y, Ouyang H-X, Jiang Z-L. A Highly Sensitive Aptamer-nanogold catalytic resonance scattering spectral assay for melamine. J Fluoresc. 2011;21(5):1907-1912.

12. Luo Y-H, Zhang X-H, Yao D-M, Wen G-Q, Liang A-H, Jiang Z-L. Resonance Rayleigh scattering detection of trace PDGF based on catalysis of an aptamer-modified nanogold probe in the Fehling reaction. RSC Adv. 2014;4(53):28052-28055.

13. Li C-N, Ouyang H-X, Tang X-P, Wen G-Q, Liang A-H, Jiang Z-L. A surface enhanced Raman scattering quantitative analytical platform for detection of trace $\mathrm{Cu}$ coupled the catalytic reaction and gold nanoparticle aggregation with label-free Victoria blue B molecular probe. Biosens Bioelectron. 2017;87:888-893.

14. Li N, Ma HM, Cao W, et al. Highly sensitive electrochemical immunosensor for the detection of alpha fetoprotein based on PdNi nanoparticles and N-doped graphene nanoribbons. Biosens Bioelectron. 2015; 74:786-791.

15. Tang J, Hou L, Tang DP, et al. Magneto-controlled electrochemical immunoassay of brevetoxin B in seafood based on guanine-functionalized graphene nanoribbons. Biosens Bioelectron. 2012;38:86-93.

16. Zhang TT, E YF. Preparation of bio-electrochemical sensor based on graphene oxide nanoribbon and its application in amino acid detection. Chin J Biochem Pharm. 2017;37(3):58-61.

17. Dong X, Long Q, Wang J, et al. A graphene nanoribbon network and its biosensing application. Nanoscale. 2011;3(12):5156-5160.

18. Zhu G, Yi Y, Han Z, Wang K, Wu X. Sensitive electrochemical sensing for polycyclic aromatic amines based on a novel core-shell multiwalled carbon nanotubes@graphene oxide nanoribbons heterostructure.Anal Chim Acta. 2014;845:30-37.

19. Baffou G, Quidant R. Nanoplasmonics for chemistry. Chem Soc Rev. 2014;43:3898-3907.

20. Jackman JA, Ferhan AR, Cho NJ. Nanoplasmonic sensors for biointerfacial science. Chem Soc Rev. 2017;46:3615-3660.

21. Milekhin AG, Cherkasova O, Kuznetsov SA, et al. Nanoantennaassisted plasmonic enhancement of IR absorption of vibrational modes of organic molecules. Beilstein J Nanotechnol. 2017;8:975-981.

22. Ishizuya $\mathrm{Y}$, Okusa $\mathrm{T}$, Hatano $\mathrm{K}$, et al. Desperation surgery for a chemorefractory lung lesion in a patient with an extragonadal germ cell tumor. Inter Cancer Conf J. 2016;5(3):154-157. 
23. Evans J. Hyperglycosylated hCG: a unique human implantation and invasion factor. Am J Reprod Immunol. 2016;75(3):333-340.

24. Roushani M, Valipour A. Using electrochemical oxidation of Rutin in modeling a novel and sensitive immunosensor based on Pt nanoparticle and graphene-ionic liquid-chitosan nanocomposite to detect human chorionic gonadotropin. Sens Actuators B. 2016;222:1103-1111.

25. Li P, Bi B-X, Li O, Yao Z-H, Yu H-Z. DNA-Redox cation interaction improves the sensitivity of an electrochemical immunosensor for protein detection. Sensors (Basel). 2015;15(8):20543-20556.

26. Yang L, Zhao H, Fan S-M, et al. Label-free electrochemical immunosensor based on gold-silicon carbide nanocomposites for sensitive detection of human chorionic gonadotrophin. Biosens Bioelectron. 2014;57: 199-206.

27. Park J-M, Jung H-W, Chang Y-W, Kim H-S, Kang M-J, Pyuna J-C. Chemiluminescence lateral flow immunoassay based on Pt nanoparticle with peroxidase activity. Anal Chim Acta. 2015;853:360-367.

28. Mazina O, Luik T, Kopanchuk S, Salumets A, Rinken A. Characterization of the biological activities of human luteinizing hormone and chorionic gonadotropin by a Förster resonance energy transfer-based biosensor assay. Anal Lett. 2015;48(17):2799-2809.

29. Lei J-Q, Mei S-R, Zhou Y-K, Jing T. A simple, selective and sensitive immunoassay for determination of human chorionic gonadotrophin based on chemiluminescence resonance energy transfer. $J$ Chin Chem Soc. 2014;61(6):638-642.

30. Yan X, Huang ZB, He M, et al. Detection of hCG-antigen based on enhanced photoluminescence of hierarchical $\mathrm{ZnO}$ arrays. Colloids Surf B Biointerfaces. 2012;89:86-92.
31. Zhao L-X, Lin J-M, Qu F. Micro-plate magnetic chemiluminescence enzyme immunoassay for rapid, sensitive determination of human chorionic gonadotropin (hCG). Acta Chim Sin. 2004;62:71-77.

32. Chang CC, Chen CP, Lee CH, Chen CY, Lin CW. Colorimetric detection of human chorionic gonadotropin using catalytic gold nanoparticles and a peptide aptamer. Chem Commun. 2014;50:14443-14446.

33. Ding X, Yang KL. Antibody-free detection of human chorionic gonadotropin by use of liquid crystals. Anal Chem. 2013;85(22):10710-10716.

34. Lei J, Jing T, Zhou T, et al. A simple and sensitive immunoassay for the determination of human chorionic gonadotropin by graphene-based chemiluminescence resonance energy transfer. Biosens Bioelectron. 2014;54:72-77.

35. Chen CY, Hwu YM, Chen CP, Chang CC. Quantitative analysis of total $\beta$-subunit of human chorionic gonadotropin concentration in urine by immunomagnetic reduction to assist in the diagnosis of ectopic pregnancy. Int J Nanomedicine. 2015;10:2475-2483.

36. Xia N, Chen Z-H, Liu Y-D, Ren H-Z, Liu L. Peptide aptamer-based biosensor for the detection of human chorionic gonadotropin by converting silver nanoparticles-based colorimetric assay into sensitive electrochemical analysis. Sens Actuators B. 2017;243:784-791.

37. Gao R, Gao Y-J, Zhao J-Z, Juo S-J, Wen T. Development of chemiluminescent immunoassay for human B-hCG. Chin J Biol. 2008;21(3): 240-243.
International Journal of Nanomedicine

\section{Publish your work in this journal}

The International Journal of Nanomedicine is an international, peerreviewed journal focusing on the application of nanotechnology in diagnostics, therapeutics, and drug delivery systems throughout the biomedical field. This journal is indexed on PubMed Central, MedLine, CAS, SciSearch ${ }^{\circledR}$, Current Contents ${ }^{\circledR} /$ Clinical Medicine,

\section{Dovepress}

Journal Citation Reports/Science Edition, EMBase, Scopus and the Elsevier Bibliographic databases. The manuscript management system is completely online and includes a very quick and fair peer-review system, which is all easy to use. Visit http://www.dovepress.com/ testimonials.php to read real quotes from published authors. 